\title{
Soft Factors of Economic Security ${ }^{1}$
}

\author{
Magdolna CSATH ${ }^{2}$ - Csaba FÁSI ${ }^{3}$ - Balázs NAGY ${ }^{4}$ - Nóra PÁLFI ${ }^{5}$ - \\ Balázs TAKSÁS ${ }^{6}$ - Szergej VINOGRADOV ${ }^{7}$
}

\begin{abstract}
The importance of economic security has increased considerably in the last decades. It can be separated into the following two parts: security of ordinary operation and security of long-term development. In this article we are going to be dealing with the latter, especially the so-called soft factors which make up the basis of it. These factors are the human capital, social capital and territorial capital. With the assistance of the tree model of competitiveness, we are going to demonstrate how important these factors are from the aspect of long-term economic development and social stability. Since the means of altering them is quite difficult and slow, developing them requires a continuous, well-considered, conscious strategy.
\end{abstract}

Keywords: economic security, competitiveness, human capital, social capital, territorial capital

\section{Introduction-The Complexity of Security}

Approaching security from different dimensions comes as no surprise to anyone these days, since security itself is not a unidimensional concept, but a multidimensional system and state with a complex character, which can only be defined by taking into account the interaction of every challenge, risk and threat that potentially or actually endangers the standard operation or sustainable development of either the individual or the social existence. This is why, the profound and professional examination of all dimensions is of vital importance since this is the only way we can ensure the future of our country and nation.

Regarding the most common version of complex definition of security, we can talk about political, military, social, economic, environmental and information security.

1 The work was created in commission of the National University of Public Service under the priority project PACSDOP-2.1.2-CCHOP-15-2016-00001 entitled "Public Service Development Establishing Good Governance” in the Ludovika Workshop.

2 Professor Emeritus, National University of Public Service; e-mail: mail@magdacsath.t-online.hu; ORCID: 0000-0002-1975-1045

3 Ph.D. candidate, National University of Public Service; e-mail: fasi.csaba@uni-nke.hu

$4 \quad$ Ph.D. candidate, University of Sopron; e-mail: nagybalazsphd@gmail.com; ORCID: 0000-0002-1229-4021

$5 \quad$ Ph.D. candidate, Szent István University; e-mail: noripalfi@gmail.com

6 Assistant Professor, National University of Public Service; e-mail: taksas.balazs@uni-nke.hu; ORCID: 00000001-7583-4198

7 Associate Professor, Szent István University; email: vinogradov.szergej@gtk.szie.hu; ORCID: 0000-00026242-3063 


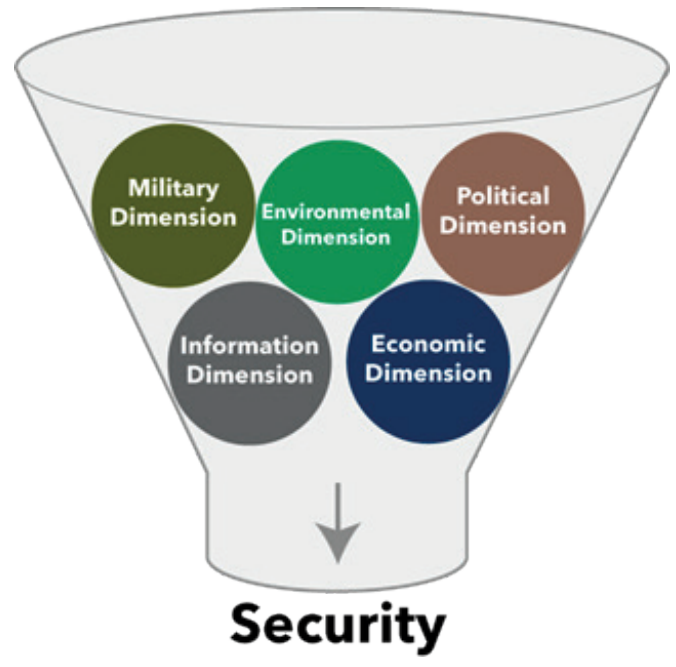

Figure 1. Dimensions of security.

[Edited by the authors.]

It is important to emphasise that linkages between certain dimensions of security are characterised by circular causality. That is to say, the sudden fall in any dimension of the security level will cause instability in other dimensions as well, which as a reaction, will decrease the security level of the previous dimension even more, causing a spill-over effect boosting itself and the entire system. In other words, if the risk in a certain dimension of security rises or activates, then in consequence, we are going to experience the activation of risks in other dimensions, as well. Because of this circular causality, new emerging risks will increase or activate in the first subsystem, which is the main reason why it is often very hard to decide from which dimension of security did the cascades of failures erupt in the first place. For instance, it can be a question whether we see general dissatisfaction, violent manifestations and a hotbed for terrorism due to the bad economic conditions and lack of opportunities for the younger generation-i.e. the youth cannot see a clear vision of their future in which they see themselves getting opportunities to improve the quality of their lives-in a certain country. Or is it the other way around? Are there bad general economic conditions and missing future visions because the capital will not go to countries infested with violent manifestations and terrorist groups? This might be a "chicken and egg” type of dilemma. Since both cause and effect are reciprocal, and also react upon one another, it is very hard to find the starting point of the process. We just simply experience the general deterioration of security.

It follows from the abovementioned circular causality that every single dimension of security needs to be dealt with equal importance. As given from such interactions, the level of political security cannot be raised higher without developing military-, economic-, social-, or environmental security as well. The same way, social security cannot be maintained without the right level of political-, economic-, or environmental security, and so on. That is to say, if the government (or international community) wishes to set the country on a path of development, the joint improvement of all dimensions is of vital 
importance, as the abovementioned spill-over effect of circular causality is positive, and it is true to mutual correction and strengthening, as well. However, in order to achieve this goal, people working in different fields with different methods and attitude, such as politicians, architects, economists, scientists, social experts, entrepreneurs, logisticians, armed forces, public administrators, and volunteers of civil organisations, need to work together in coordination. This can be an incredibly huge challenge.

In this article we are dealing with the economic dimension of security, more exactly, its factors defining its long-term condition, taking the so-called "soft-factors" (e.g. human capital, social capital, etc.) into special consideration, which make up the basis of longterm development, and which are always difficult to examine or analyse (compared to hard factors). Therefore, our research team has taken up the task of studying their conditions in Hungary. In this article, we are going to present the roles of soft factors in economic security, and also outline the most important challenges and risks we have to take into account in this field.

\section{Economic Security}

Economic security can be interpreted as the condition, where the risks for activation of factors and processes threatening the normal economic operation and sustainable growth is not higher than the normal range. Consequently, the economic policy assets and organisations can perform their tasks using normal algorithms and methods and a higher level of state (economic policy) intervention is not required. Furthermore, the economy is able to fulfil the demands on economic operations when countering a threat, danger or risk emerging in any other dimensions of security. [1]

Building on this definition, economic security basically has an aspect dealing with operations and another one dealing with development. The previous one, called operation security, studies to what degree risks and threats endanger the everyday operations and the capability to fulfil the basic functions of the economy. Furthermore, it studies the way economy is able to meet the demands in case any other security challenge emerges in a given period of time. Development security deals with the conditions ensuring the quality of continuous development in the domains of the economy and society and the way a country is able to retain or improve its taken position in the global economy.

Of course there is a strong relation between the two aspects since economy uses up resources for both daily operation and long-term development, therefore the existence or non-existence, as well as the quality of these resources determine both the present operation and the future development. However, both of these factors are typified by different risks and can be exposed to different threats, as well.

In this article we are going to focus on development security. The importance of studying development security is supported by the common definition of security, saying: security ensures future welfare. 


\section{The Factors of Development Security}

The concept of development security has been explored by several researchers. At the beginning of our prolonged research, we summed up the factors ensuring development security in the following figure: [2]

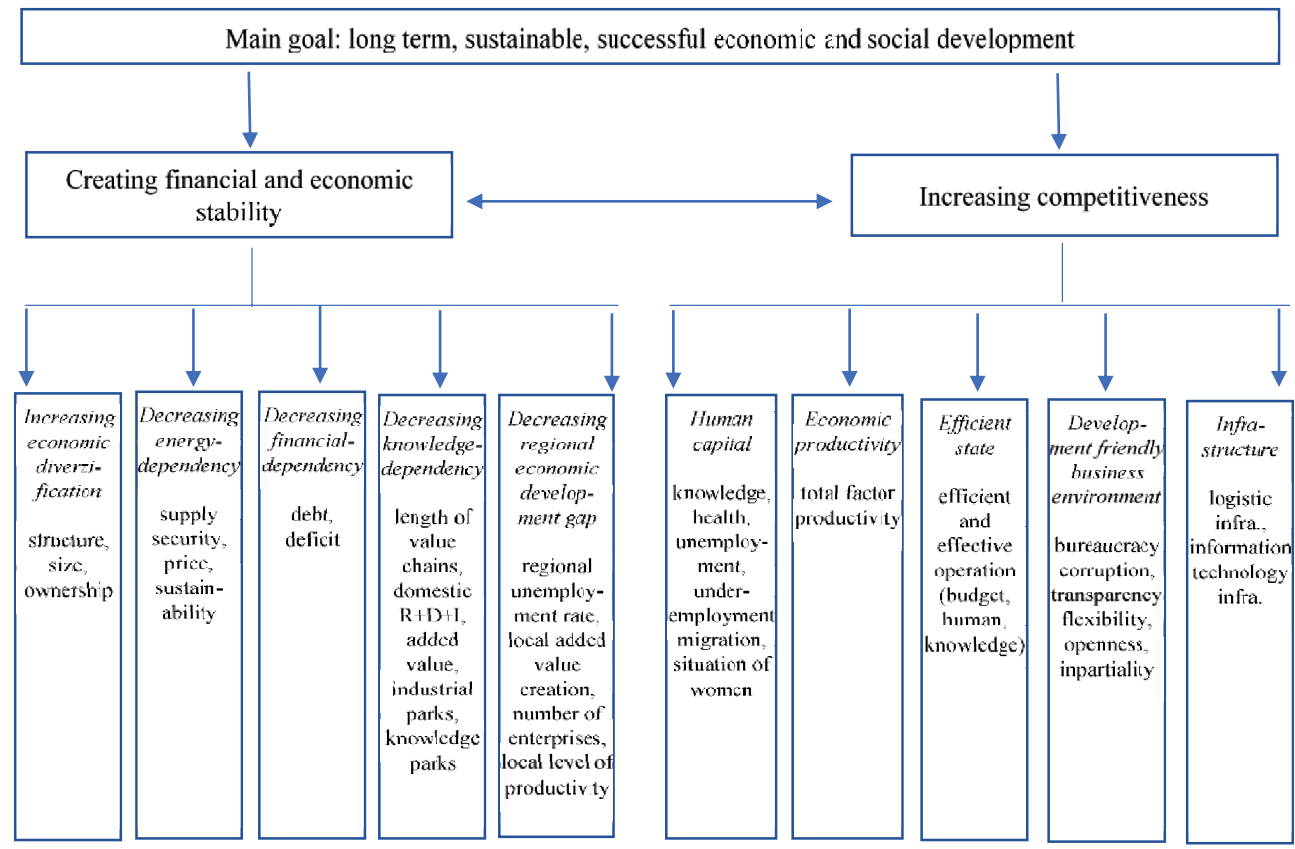

Figure 2. Development security elements. [11]

It is well-seen in Figure 2 that from the aspect of ensuring long-term development, it is important to decrease the degree of any exterior dependency of our economy (e.g. financial, knowledge, technology, information, energy, etc.). Naturally, in our globalised world today-which is best described by the interdependence of national economies-there is no country, which would be able to overcome exterior dependency. However, in economic relations, it is important to mitigate the dependency as much as possible-by becoming the less-dependent superior participant, instead of the inferior more-dependent-since this is what ensures the higher state of development in the long run. [3]

On the other hand, it is important to establish and improve those economic and noneconomic factors which increase the competitiveness of the country, and through this, also its potential for improvement and expansion. Experts all agree that the higher state of competitiveness leads to better quality of life, higher social satisfaction and greater happiness. However, there is a difference among the opinions about how necessary it is in the society to make short-term sacrifices causing a huge drop in the standard of living or in happiness, in order to increase competitiveness. According to most opinions, such sacrifice is necessary to a certain degree. To mention a few examples of sacrifice: in order to decrease exterior financial dependence and to finance research, development and innovation-which 
gives the basis of competitiveness, and related investments - a high internal saving rate is needed. [4] This means, in order to improve long-term competitiveness, people have to give up some portion of their consumptions, which will decrease their satisfaction and their level of happiness consequently. The same way, improving competitiveness and quality of life requires environmentally aware and more resource-economical lifestyle from economic participants (from all households, enterprises and governmental organisations) [5] which means short-term discomfort, and giving up or changing accustomed ways of behaviour. This is an equivalent case when a change of national or organisational culture is required in order to enhance competitiveness. ${ }^{8}$

Although the previously mentioned relations were only given as examples, it can already be seen from these that competitiveness has a significant background of social factors. From the numerous existing models, we would like to present the complex system of competitiveness based on the competitiveness tree model. It was created by the Ecorys research team run by Jan Maarten de Vet. [6] Edited and extended with the results of our research team, the tree will look in the following way:

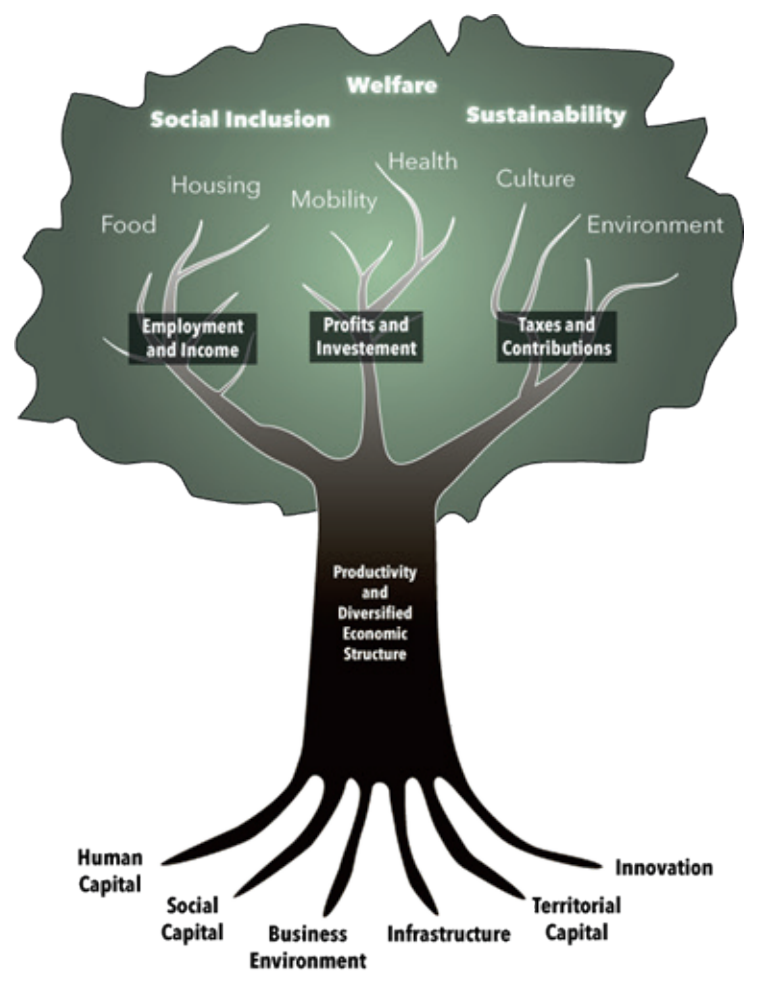

Figure 3. Competitiveness tree.

(Modification of [6].)

8 The bigger the requirement for changes, the bigger the inconvenience and dissatisfaction resulted by these changes in the short term. We can think about famous historical examples: the reforms of the Russian Tsar Peter the Great or the whole cultural changes lead by Kemal Ataturk and the big social dissatisfaction they caused. 
The competitiveness tree presents the logical connection between the elements of competitiveness on the one hand, and on the other hand, it shows that competitiveness is not a one-way process, but_-as nature itself_-it exists within a continuous cycle.

The roots of the tree symbolise the factors a country's competitiveness relies on. These are the factors which have been extended throughout our research compared to the original figure of the Ecorys research team. A competitive economy-just like a tree-can only grow with strong and healthy roots, which, in our case, means a good social and business basis.

So, what does "healthy roots" mean, in our case-from the aspect of competitiveness? The main factors are: human capital, innovation, infrastructure, business environment, social capital, territorial capital. Only in the case of existence and well-operation of these factors can a healthy, strong trunk develop, which makes up the frame of competitiveness: diversified economic structure with a high level of productivity.

As branches derive from the trunk and make up the foliage on which the fruits grow, the same applies to competitiveness: the highly productive, diversified economic structure will result a high level of employment, high income, profit, high investment rate, and adequate governmental tax income. These factors will create possibilities for better health conditions, fulfilling other biological needs (food and housing), cultural life, natural environment, mobility, which will eventually result in the most important fruits of the competitiveness tree: prosperity, environmental-, economic-, social sustainability and social inclusion. In case of a competitive economy, economic development, social inclusion and cohesion are more sustainable. It is easier to adapt using environment-friendly, smart and clean technologies, as well as in a competitive economy. [5] [7] Just as the soil and roots require the foliage and fruits to be recycled by falling on the ground and keeping the cycle in operation by renewing the soil, something similar is necessary to operate the competitiveness tree: just like in nature, the factors in the roots of our tree are nourished by its foliage and fruits.

The model presenting the cycle above explains very well, why it is impossible to form a competitive economy out of nothing. In order to rise, develop and turn a tree or an orchard productive, time and constant care is required. The same thing applies to creating public welfare, since it cannot be done from one day to another, either. This is what politicians and social leaders often do not understand-how the cycle works: growing roots, a strengthening trunk, more and more branches, expanding foliage, more fruits, more leaves and fruits falling onto the ground, which will then help the expansion of the root and its ability to nourish the whole tree. Competitiveness grows in such an integrated cycle. However, as a tree can dry out or wilt any time, the same way can the process of competitiveness and welfare development stall or dissolve. Also, as in the case of the death or weakening of a tree, the most frequent and dangerous cause is the weakening of the root, behind the failure of competitiveness, we can usually find having aggravating problems with some basic factors, as well. This is why it is vitally important to search the roots of competitiveness and this is the reason why our research team has been focusing on these factors for so long. 
M. CSATH - CS. FÁSI - B. NAGY - N. PÁLFI - B. TAKSÁS - SZ. VINOGRADOV: Soft Factors...

\section{The Roots of Competitiveness}

As an analogy, the primary roots of a tree, which consist of numerous secondary roots and root hairs, the factors described here as the root of competitiveness are also collective concepts. The quality of these concepts depends on their ability of supporting competitiveness and the elements belonging to them. These concepts include but are not limited to the following factors:

- human capital: knowledge and skill, health, business (entrepreneur) knowledge, willingness for lifelong learning;

- social capital: equality and social integration, regional cohesion, entrepreneur attitude, openness, trust and cooperation, resiliency, willingness to save, long-term (strategic) thinking, honesty;

- business environment: access to resources and technology, fair and strong competition, effective and supportive state (good governance), predictable legal environment, low level of bureaucracy, internalisation;

- infrastructure: transportation and logistics infrastructure, information technologic infrastructure, energetic infrastructure;

- territorial capital: natural environment and natural resources, local social and economic network, local institutional system and services, local culture and entity, attraction, network capital;

- innovation: research + development + innovation, property rights, technological knowledge, know-how.

After examining the root of the competitiveness tree, the cycle of the system becomes clear since the standards of the above factors can only be maintained by the constant investment of business and government spheres. Besides, it can be seen that in order to establish and maintain the basics of competitiveness, appropriate social, educational, environmental and cultural policy is necessary. The following is an important statement: the security of economic development is not an independent economic policy matter. (It does not belong to only one policy area, and there is not a single policy area which has to deal with it. Competitiveness tasks involve a great deal of responsibility and effort for the whole government.) Therefore, planning and implementation need to be handled at strategic level, since without a high degree of coordination, independent activities of certain policy areas can extinguish or weaken the activities of other policy areas intending to strengthen competitiveness.

Our research team has modified the original figure of the competitiveness tree in order to make it possible for the so-called soft and hard factors to be shown separately. On the root section of the model created by our team, the infrastructure is the only part which can be considered classically a "hard factor". (Maybe innovation also belongs to this category.) All the other groups belong to the so-called "soft-factors". We can establish an important statement based on the model: the security of long-term economic development relies on the factors of competitiveness which are quite elusive, hard to interpret and measure, therefore they are hard to improve, as well.

Although the mapping of these factors might belong to the hardest parts of understanding competitiveness, the members of our research team have been working on them for a long 
time. The development and competitiveness analysis which was the professional basis for separating Pest County from Budapest and making it an independent region of the European Union was done by the principal investigator of the team, Magdolna Csath, and a team member, Balázs Nagy in 2015. A measurement model, similar to the structure of the competitiveness tree was created for this task, which has put a huge emphasis on measuring the factors building up the basics (the root) of competitiveness. [8] [9] ${ }^{9}$ We have applied a similar model with the logic of layers relying on one another, to measure how much is the competitiveness of a region supported by the (quantity and quality of) the logistical infrastructure in certain regions of Hungary. [10] Physical infrastructure also belongs to the root of the tree. As the next step, between 2016 and 2017, our team did a research regarding the quality of business environment in Hungary, in which we were focusing on the role of the Hungarian state and have also looked at its preventive or supportive nature. As part of our research, we asked for the opinion of approximately 1,500 enterprises through surveys and personal interviews. The sizes of these enterprises range from oneperson businesses to multinational companies located in Hungary. This huge work was completed by interviewing family-owned enterprises in the Czech Republic and Slovakia, asking questions on the same topic. The 300 pages long report was handed to the State Reform Committee in June 2017. [11] In the second half of 2017 we have continued our research with exploring the other two soft factors, namely human capital and social capital.

\section{The Role of Social Capital, Human Capital and Territorial Capital in Competitiveness}

The alternation of the original competitiveness tree-especially having the factors presented at the root re-structured-is the result of many years of research done by us. Therefore, we included such summarising concepts as human capital, social capital and territorial capital.

Human capital means the contribution of people to economic activity. Contribution, in this case, can be anything created with work, creativity, imagination, emotions or senses. It is called capital, because it is made by investment in human resources. The more skilled and the healthier are the citizens, the more can human resources contribute to economic activity. The level of skills and knowledge is provided by the educational system and its health is created and ensured by the means of the health care system. The sustainment of these systems requires capital investment (from the part of society and/or individuals).

Human capital is the key to economic activity. This is why it became represented in the figure of the competitiveness tree. Creating and sustaining research-development, innovation and highly complex technologies requires human knowledge, skills and abilities. Besides, for a considerable part of production and service procedures, human labour is required. Therefore, the higher level human capital skill and knowledge is in a country, the higher the level of economic security will be, and the more ensured the possibility of long-term development will be. [12]

Social capital consists of the basic norms, set of values, attitude and other characteristics. [13] From the perspective of competitiveness there are some kinds of social

9 The cited papers are the summaries of the research. 
attitudes which support economic development even more. If society is open towards new ideas, the level of trust and cooperation is high among its members, they do not expect the government to solve all their problems, they have entrepreneur spirit, they are prone for initiatives, and if all these pair up with a long-term oriented mindset, development security will be on a higher level.

The basis of economic activity is entrepreneurship and cooperation. The higher the level of technology we use and the more complex are the activities we do, the more cooperation we need. And the basis of cooperation is trust. If there is a higher level of trust between participants, we share information easier. Which means, in a society, in which trust is stronger between the members and participants of economy (households, enterprises, financial institutes, governmental and non-profit organisations), will reach a higher level of cooperation and faster economic development. In case of having strong social capital, making and maintaining business contacts is also less expensive. If there is less need for risk averse contracting techniques and administrative measures, this can also lower the burden of the red tape. In countries with strong social capital, there are many cooperative efforts built from the ground up, which weakens hierarchic, dependent relations and as a result will strengthen democracy. [14]

Resiliency is also a key element of social capital and long-term economic development. Resiliency means first of all that an economy is being ready for the possible long-term threats. [15] On the other hand, it means that a resilient system is one that can recover to some workable points despite changes and hardships. In terms of an economy, it is suggested that diversified economies are more resilient. Resiliency can also be analysed regionally, in order to examine how sustainable local communities are.

Unlike human capital, social capital cannot be increased or improved by investing money into it, since strengthening social capital requires strong common norms, honesty, loyalty and reliability. [16] However, having certain individuals possessing such qualities is not enough. These norms have to become universal, for which social and political leaders are required to set a consequent example. Since social capital can be understood as the force which keeps society together, cohesion becomes a component of it, between both the social classes and the geographical regions. This means that from the aspect of competitiveness and long-term development, it is very important to avoid serious inequalities in property and income. The reason for this is that huge social inequality will not only cause problems (social tension, crime, tendency for religious or political extremism, etc.) in the short run, but it will also decrease the pace of long-term economic development, since-as generally admitted by economists [17] — it worsens the condition of economic development. On the one hand, on the supply side, because sooner or later there will be a huge lack of well-trained, skilled and healthy manpower on the labour market. On the other hand, on the demand side since the most part of society does not have the purchasing power which would enable them to consume products of high added value. The disruption on both sides of the market will become an obstacle for innovation. Therefore, the keyword is inclusiveness. It means, that each member of society can have a part in the results of economic development and can have an opportunity to contribute to it, too. [18] It can be realised by equally ensuring security, social engagement, and access to high level of education and medical care. [17] [18] Otherwise, the country loses human capital. The contribution of lost and wasted human capital will be missing in economic accomplishment. [17] 
It can be seen, that high standard of education and public health (and the access to these) appears in connection with both human and social capital. That is why these two areas can be considered the key for long-term economic development.

Territorial capital includes all physical and non-physical, tangible and intangible -immaterial-local values. [19] As OECD described it, territorial capital refers to the stock of assets which form the basis for endogenous development in each city and region, as well as to the institutions, modes of decision-making and professional skills to make best use of those assets. [20] It includes the area's geographical location, size, factor of production endowment, climate, traditions, natural resources, quality of life or the agglomeration economies provided by its cities, but also includes its business incubators and industrial districts or other business networks that reduce transaction costs. Other factors may be "untraded interdependencies" such as understandings, customs and informal rules that enable economic actors to work together under conditions of uncertainty, or the solidarity, mutual assistance and co-opting of ideas that often develop in clusters of small and medium-sized enterprises working in the same sector. Lastly, there is an intangible factor, "something in the air", called the "environment", which is the outcome of a combination of local institutions, rules, practices, producers, researchers and policy-makers, that make a certain creativity and innovation possible. [20]

The connection between territorial capital and social capital is that strong social capital and cooperation attracts creative and innovative people, who will then strengthen local, social and cultural connections even further. [14] And in reverse, for possessing strong social capital, it is important not to have big differences among the level and quality of territorial capital in different regions of the given country.

From the description of these soft factors, it will again become understandable, that improving competitiveness and establishing development security is an ongoing cycle which can be well-presented with a natural comparison, the competitiveness tree. These soft factors require constant care and improvement. It also requires fostering care by helping to revitalise the soil by its falling fruits of competitiveness and welfare.

It is very important to see, that human, social and territorial capital are all such factors, which can only be improved in the long run. The level of people's qualification and health cannot be improved in the short run. Society's set of values and social norms cannot be changed from one day to another. The attractiveness and immaterial values of a region cannot be established within a short period. This means, that the root's healthy development on the competitiveness tree is a long-term process. Therefore, if development security falters in a country, it is very hard to change these conditions. This is why tending all soft factors carefully and continuously (which requires both extensive intellectual and financial investment) is of high priority, otherwise the country and the country's economy can easily be exposed to such damage which is possibly beyond repair.

\section{Main Challenges}

Throughout our research, we certainly considered and analysed the challenges and risks constituting the greatest danger to the developing dimension of economic security. We paid special attention to those in connection with the soft factors analysed in the previous 
chapters. If we would like to brief the most important ones, we can list the followings: 1 . globalisation and trans-nationalisation; 2. automation and robotization; 3. natural resource depletion, climate change and green competitiveness.

In addition to the numerous advantages of globalisation, it also has many potential risks towards competitiveness and its soft factors. One of the most important ones is the fact that there is a shift in income-share, from the employee towards the capital owner in the world, and also-if the government does not interfere-that globalisation increases social differences. Automation and robotization-being a new industrial revolution-gives a strong push to economic improvement; however, it will incredibly expand the labour market in the next decades, as it might as well extend the whole global society.

Finally, the natural resource depletion and climate change-sooner or later (there are debates about the possible datum)—will totally change our globe and the presence of mankind on it.

The study of these challenges exceeds the cadre of this article, however, we can affirm that these processes and phenomena will be and are already changing the fundaments of the social structure and economic activity. We are clearly facing delays in the preparation, and those nations who have fallen behind will definitely face an extreme damage in every dimension of the quality of life (living standards, social inclusion, environmental quality etc.).

As every fundamental change, the preparation for these challenges also starts with the roots. Which means in this case the soft factors of the economy, the soft factors of the development security. Among others, we have to redefine the role of the education system, change the labour market and social policy instruments, the social network elements, the taxation system, rethink the role of the state in the redistribution system and certainly totally modify all of our production processes and consumption behaviours.

\section{Summary}

Economic security has a key importance in our globalised world today. We can find economic issues, economic background behind every conflict, every security risk. So, it is very important to be able to understand the complexity of the economic security system and to analyse the roots of it.

Economic security can be divided into operation security and development security. In order to be able to reach long-term security and defence goals, we have to deal with development security questions for creating sustainably prospering economic environment. It is hard to write a short summary of the field of development security, as the system is extremely complex and facing at least as complex challenges as it is. Our research group further developed the already existing model of the competitiveness tree, which shows the circular system of interactions. If its root is not nourished continuously with its fruits, growth will stop. In other words, if we do not return the results of economic development to social, economic and natural environmental factors, which assure long-term economic development, it will hamper or might as well show a downward tendency. Without a healthy root system, we cannot develop a strong and resilient trunk, which means in economic terms 
high productivity and diversified economic structure. For decreasing economic dependency and economic security risks, diversified economic structure is indispensable.

Therefore, it is vitally important to deal with the basics of economic development, which we have grouped in the following way: innovation, human capital, social capital, business environment, infrastructure and territorial capital. In this article, we referred to the soft factors, as human, social, and territorial capital. We presented their components and stated them critical elements because they can only be edited in the long run. That is to say, their development requires continuous, well-thought and conscious strategy. If we neglect this, the competitiveness of the country will weaken, and it is not possible to be changed back quickly, in a short period, even if all the politicians of the country wished it together. In addition, we need to discover, learn and prepare for challenges and risks which occur regarding long-term economic development.

And finally, if we are able to create a resilient and competitive environment, we can control the activation of the economic security risks, and the stability of the national economy will also contribute to an improving security in the political and military dimension.

\section{References}

[1] TAKSÁS B.: A biztonság gazdasági dimenziójának jellemzői, a gazdasági biztonság szintjének mérése. Hadtudományi Szemle, 92 (2016), 142-151.

[2] CSATH M. - ALFÖLDY-BORUSS M. - GYŐRPÁL T. - NAGY B. - TAKSÁS B.: Pénzügyi stabilitás és versenyképesség. In. KAISER T. - KIS N. szerk: A Jó Állam mérhetősége. Budapest, NKE Szolgáltató Kft., 2014. 89-139.

[3] SZENTES T.: A világgazdaságtan elméleti és módszertani alapjai. Budapest, Aula Kiadó, 1995.

[4] MANKIW, N. G.: Makroökonónia. Budapest, Osiris Kiadó Kft., 2005.

[5] The Sustainable Competitiveness Report, 2016. Zurich, SolAbility, 2016.

[6] DE VET, M. J. - BAKER, P. - DALGLEISH, K. - POLLOCK, R. - HAELY, A.: The Competitiveness of Places and Spaces. A Position Paper. Rotterdam-Leeds-BirminghamBrussels, Ecorys, 2004.

[7] The Measurement of Sustainable Competitiveness. Geneva, World Economic Forum, 2014. http://reports.weforum.org/global-competitiveness-report-2014-2015/the-measurement-ofsustainable-competitiveness/ (Downloaded: 27.02.2018)

[8] CSATH M.: A regionális versenyképesség mérése társadalmi-gazdasági mutatók alapján. Pest megyei esettanulmány In. CSATH M. szerk.: Regionális versenyképességi tanulmányok. Budapest, NKE Szolgáltató Nonprofit Kft., 2016. 73-109.

[9] NAGY B.: Regionális versenyképességi különbségek Magyarországon egy kompozit mutató alapján. In. CSATH M. szerk.: Regionális versenyképességi tanulmányok. Budapest, NKE Szolgáltató Nonprofit Kft., 2016. 109-143.

[10] LAKATOS P. - SZÁSZI G. - TAKSÁS B.: A logisztikai infrastruktúra szerepe a regionális versenyképesség alakításában. In. CSATH M. szerk.: Regionális versenyképességi tanulmányok. Budapest, NKE Szolgáltató Nonprofit Kft., 2016. 181-228.

[11] CSATH M. - NAGY B. - TAKSÁS B. - VINOGRADOV Sz. - GYŐRPÁL T.: Jelentés az állam versenyképességet javító, vállalkozóbarátabb üzleti környezet megteremtését célzó, 
M. CSATH - CS. FÁSI - B. NAGY - N. PÁLFI - B. TAKSÁS - SZ. VINOGRADOV: Soft Factors...

szükséges és lehetséges feladatait vizsgáló kutatásról. Államtudományi Múhelytanulmányok, 4 (2018).

[12] CSATH M.: A gazdasági biztonság, mint a nemzeti biztonság egyik pillére. Társadalom és Honvédelem, 193 (2015), 5-18.

[13] PUTNAM, R. D. - LEONARDI, R. - NONETTI, R. Y.: Making Democracy Work: Civic Traditions in Modern Italy. Princeton, Princeton University Press, 1994. DOI: https://doi. org/10.2307/j.ctt7s8r7

[14] CSATH M.: Versenyképesség nemzeti, nemzetközi és regionális szinten. In. CSATH M. szerk.: Regionális versenyképességi tanulmányok. Budapest, NKE Szolgáltató Nonprofit Kft., 2016. 15-40.

[15] HACKLER, D.: Resiliency, Competitiveness and Innovation. Government Finance Review, 2 (2012).

[16] FUKUYAMA, F.: Trust: The Social Virtues and The Creation of Prosperity. New York, Free Press, 1996.

[17] OECD: Economic Policy Reforms 2017: Going for Growth. Paris, OECD Publishing, 2017.

[18] Defining Sustainable Competitiveness. Geneva, World Economic Forum, 2014. http:// reports.weforum.org/global-competitiveness-report-2014-2015/defining-sustainablecompetitiveness/ (Downloaded: 01.03.2018)

[19] JÓNA Gy.: A területi tőke fogalmi megközelítései. Tér és Társadalom, 271 (2013), 30-51. DOI: https://doi.org/10.17649/tet.27.1.2449

[20] OECD: Territorial outlook. Paris, OECD Publishing, 2001. 